\title{
Daya Saing dan Potensi Ekspor Melati Putih Segar Uasminum sambaac) Indonesia
}

\author{
Liska Simamora ${ }^{*}$, \\ Hendrik Johannes Nadapdap ${ }^{2}$ \\ 1,2 Fakultas Pertanian dan Bisnis, Universitas Kristen Satya Wacana, Indonesia \\ *email: liska.simamora@uksw.edu \\ Diterima: Maret 2021; Disetujui: September 2021; Dipublish: Oktober 2021
}

\begin{abstract}
Abstrak
Kementerian Pertanian berupaya untuk meningkatkan ekspor bunga melati putih. Upaya tersebut akan lebih cepat terwujud jika daya saing dan pengembangan potensi komoditas di berbagai negara tujuan ekspor diketahui. Penelitian ini bertujuan untuk mengetahui daya saing dan pengembangan potensi ekspor bunga melati putih. Data yang digunakan adalah data time series 2010-2019 yang bersumber dari UN-COMTRADE dan trade map. Analisis data menggunakan Revealed Comparative Advantage untuk mengetahui daya saing komoditas, dilanjutkan dengan Export Product Dynamic untuk mengetahui posisi pasar komoditas dan tahap terakhir dengan analisis X-model untuk mengetahui potensi pengembangan ekspor. Hasil penelitian menunjukkan bahwa daya saing bunga melati putih Indonesia kuat di China, Jepang, Australia, Vietnam, Singapura dan Amerika Serikat dan bahwa bunga melati putih Indonesia memiliki potensi dalam kategori optimis di Australia, Vietnam dan Singapura serta potensial di China. Jepang, Belanda, Inggris, dan Amerika Serikat. Potensi pasar yang optimis dan potensial ini dapat direbut oleh Indonesia dengan mengupayakan kualitas bunga melati putih yang sesuai dengan syarat yang dikehendaki negara tujuan ekspor.
\end{abstract}

Kata Kunci: Ekspor; EPD ; Melati Putih; RCA; X-Model

\begin{abstract}
The Indonesian Ministry of Agriculture is working to increase exports of Indonesian white jasmine flowers. These efforts will be realized more quickly if the competitiveness and development potential of commodity in various export destination countries are known. Therefore, this study aims to determine the competitiveness and development potential of white jasmine flower exports. The data used is the 2010-2019 time series data sourced from UNCOMTRADE and the trade map. The data were analyzed by using RCA to determine the competitiveness of commodities, followed by EPD to determine the position of the commodity market and the last stage with the X-model analysis to determine the potential for export development. The results show that the competitiveness of Indonesian white jasmine flowers is strong in China, Japan, Australia, Vietnam, Singapore and the United States and that Indonesian white jasmine flowers have potential in the optimistic category in Australia, Vietnam and Singapore and potential in China, Japan, Netherlands, United Kingdom and United States. This optimistic and potential market potential can be seized by Indonesia by striving for the quality of white jasmine flowers in accordance with the demands of export destination countries.
\end{abstract}

Keywords: EPD; Export; RCA; X-Model; White Jasmine

\section{PENDAHULUAN}

Purwaning Astuti \& Juniwati Ayuningtyas, (2018) menyatakan bahwa Dalam jangka panjang, jumlah ekspor dan tingkat kurs rupiah berpengaruh signifikan terhadap pertumbuhan ekonomi. Ekspor dan investasi memegang peranan penting 
dalam perekonomian suatu negara. Devisa yang diperoleh dari transaksi ekspor digunakan untuk membiayai impor bahan baku dan barang modal yang diperlukan dalam proses produksi yang akan membentuk nilai tambah dimana agregasi nilai tambah semua produk dan jasa menjadi nilai Produk Domestik Bruto (PDB). Semakin bertambahnya volume ekspor maka akan meningkatkan nilai PDB suatu negara. Di Indonesia, sebagai negara agraris, sektor pertanian adalah salah satu lapangan usaha yang keberadaannya tidak dapat dipandang sebelah mata karena produk pertanian menjadi komoditas ekspor yang sangat berkontribusi terhadap penambahan jumlah PDB meskipun tren ekspor pertanian Indonesia sangat fluktuatif seperti yang ditunjukkan Tabel 1.

Tabel 1: Perkembangan Ekspor Produk Pertanian tahun 2012-2018

\begin{tabular}{ccrr} 
Tahun & $\begin{array}{c}\text { Berat Bersih } \\
\text { (ribu ton) }\end{array}$ & Nilai (juta US\$) & $\begin{array}{c}\text { \% Perubahan } \\
\text { Nilai }\end{array}$ \\
\hline 2012 & 2268,4 & 3597,7 & 6,16 \\
2013 & 2462,2 & 3598,5 & 0,02 \\
2014 & 2777,3 & 3373,3 & $-6,26$ \\
2015 & 3621,5 & 3726,5 & 10,47 \\
2016 & 3453,0 & 3354,8 & $-9,98$ \\
2017 & 4177,7 & 3671,0 & 9,43 \\
2018 & 4345,4 & 3431,0 & $-6,54$ \\
\hline
\end{tabular}

Sumber: (BPS, 2019)

Komoditas hortikultura adalah salah satu komoditas dalam 9 pengelompokan elemen sektor pertanian yang potensi ekspornya tinggi. Berdasarkan keterangan (Kemenko RI, 2019) Sub-sektor Hortikultura memberikan kontribusi rata-rata $14 \%$ terhadap PDB sektor pertanian pada tahun 2014-2018 dan selanjutnya diinfokan bahwa Pada 2018, nilai ekspor hortikultura senilai US\$ 439.574 merupakan urutan ke-2 tertinggi setelah tanaman perkebunan

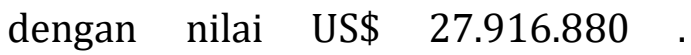
Tanaman hias menjadi salah satu komoditas Sub-sektor Hortikultura.

Horti Indonesia (2020) menginfokan bahwa nilai perdagangan tanaman hias dunia bernilai US\$ 89,5 dengan distribusi yakni sebanyak $55 \%$ merupakan florikultura, $35 \%$ tanaman berkayu dan $10 \%$ jenis lain. Nilai pasar ritelnya di dunia mencapai US\$22,39 miliar dimana angka ini dinyatakan melebihi nilai pasar ritel teh dan kopi. Salah satu komoditas tanaman hias yakni melati putih (Jasminum sambac) yang juga dikenal sebagai puspa bangsa di dalam negeri adalah komoditas yang sangat diperlukan baik di dalam maupun di luar negeri. Adapun kegunaan daripada komoditas ini terkhusus bagian bunganya adalah menjadi elemen penting dalam upacara religi dan untuk upacara adat pada berbagai suku. Selain itu, bunga melati putih ini juga menjadi bahan 
baku untuk industri obat-obatan, kosmetik, parfum, dan juga sebagai bahan campuran untuk industri teh.

Selain sangat dibutuhkan untuk konsumsi di dalam negeri, bunga melati putih Indonesia juga dibutuhkan oleh negara lain. Hal tersebut ditunjukkan oleh adanya aktivitas ekspor bunga melati ke berbagai negara. Adapun negara tujuan utama dan nilai ekspor bunga melati putih dalam kurun waktu tahun 2010 hingga 2019 secara berurut dengan nilai ekspor tertinggi hingga terendah adalah China (US\$1.684.269), Vietnam (US\$ 542.427), Australlia (US\$ 132.757), Belanda (US\$ 118.441), Singapura (US\$ 103.799), Amerika Serikat (US\$ 40.295), Jepang (US\$ 25.494), Malaysia (US\$ 11.988), Inggris (US\$ 3.103) (UN COMTRADE, 2021). Berdasarkan data UN COMTRADE (2021), negara Vietnam dan Jepang adalah dua negara tujuan ekspor sebanyak 9 kali berturut-turut disusul oleh negara China dan Australia sebanyak 8 kali dan Singapura sebanyak 7 kali. Frekuensi tujuan ekspor yang tinggi menunjukkan bahwa ada permintaan luar negeri yang sangat potensial untuk dipenuhi komoditas bunga melati putih Indonesia.

Hal penting lainnya yang perlu diperhatikan adalah berhentinya aktivitas ekspor ke tiga negara tujuan paling terakhir yaitu Belanda, Inggris dan Amerika Serikat terhitung mulai tahun 2016-2019. Posisi ekspor melati putih negara Indonesia diantara beberapa negara eksportir utama lainnya mulai tahun 2010-2019) ditunjukkan seperti pada Gambar 1. Gambar tersebut menunjukkan bahwa pada tahun 2010-2012 ekspor melati putih Indonesia sempat mengalami kenaikan. Masih dari Gambar 1, diperlihatkan bahwa negara yang ekspor melati putihnya terus meningkat adalah negara Ekuador. Hal ini menunjukkan bahwa negara Ekuador menjadi pemasok utama melati putih untuk berbagai negara di Benua Amerika dan Eropa.

Sejak tahun 2018 pemerintah sudah berupaya untuk meningkatkan ekspor bunga melati segar salah satunya adalah seperti yang diuraikan di dalam (Badan Karantina Pertanian RI (2019) dengan memperketat pengawasan kesehatan bunga melati putih supaya terbebas dari serangan hama dan penyakit sehingga dapat diterima dengan baik oleh negara tujuan ekspor. Upaya pe ningkatan ekspor bunga melati putih ini tentunya semakin realistis untuk direalisasikan karena adanya potensi pasar sebagaimana telah diuraikan di atas.

Kondisi iklim Indonesia yang mendukung pertumbuhan tanaman hias terkhusus bunga melati putih ini memungkinkan bahwa negara Indonesia bisa menjadi salah satu pemeran penting dalam mencukupi permintaan dunia. Hal ini menjadi peluang bagi negara Indonesia supaya meningkatkan daya saing ekspor bunga melati putih sehingga menjadi komoditas yang unggul untuk dipilih negara importir dibandingkan produk serupa dari negara lain. Menurut Muttoharoh et al., (2018); Kurniawati 
et al., (2019) bahwa daya saing ekspor komoditas pertanian yang dimiliki oleh suatu negara dipengaruhi oleh produksi komoditas dan kurs; harga internasional. Kemampuan daya saing yang unggul suatu komoditas mampu meningkatkan kinerja ekspor suatu negara. Berdasarkan hal tersebut, maka penelitian ini bertujuan untuk mengetahui daya saing dan potensi peningkatan ekspor bunga melati putih Indonesia.

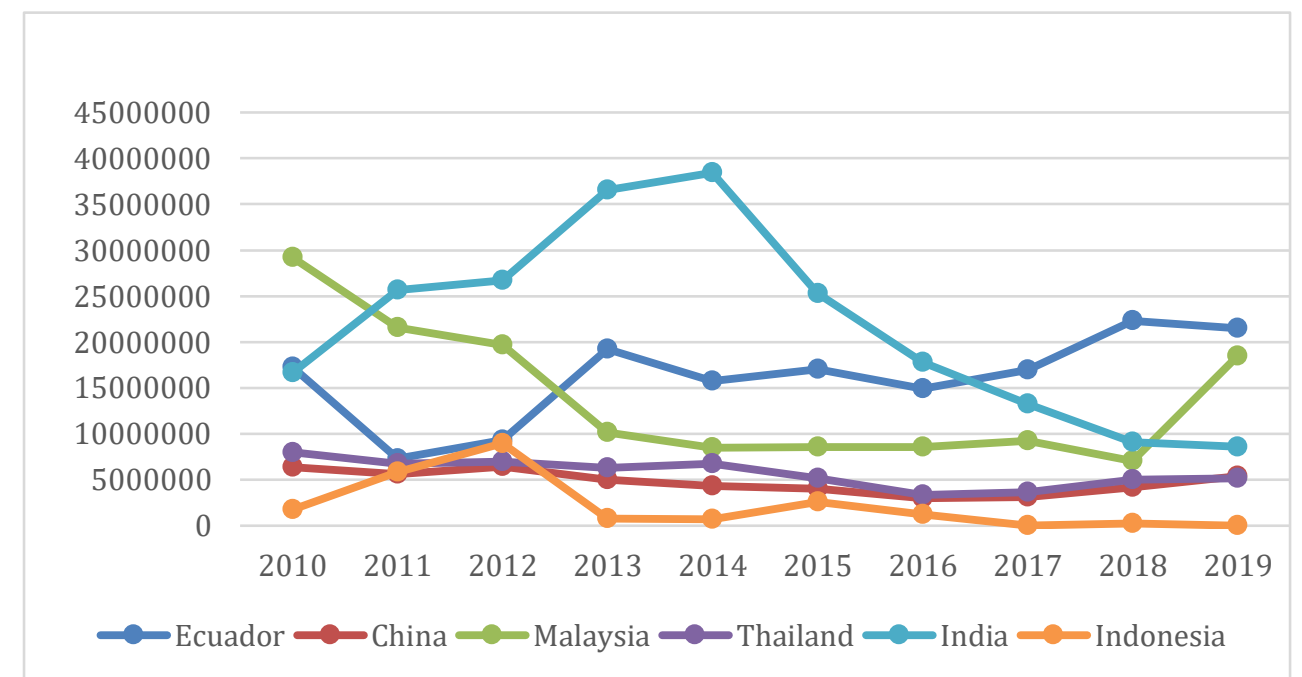

Sumber: UN COMTRADE 2020 (Diolah)

Gambar 1: Nilai Ekspor Bunga Melati Berbagai Negara

Dengan tersedianya informasi akan daya saing bunga melati putih, maka akan membantu pemerintah dan pihak lain yang terkait dalam mewujudkan suksesnya ekspor komoditas ini. Namun, belum terdapat publikasi terdahulu yang menjelaskan tentang posisi daya saing serta potensi ekspor bunga melati putih Indonesia.

Berdasarkan uraian di atas, maka penelitian ini bertujuan untuk melakukan analisis daya saing serta potensi ekspor komoditas bunga melati putih Indonesia.

\section{METODE PENELITIAN}

Penelitian ini menggunakan data sekunder dengan kode HS yang diperoleh dari UN-COMTRADE dan Trade Map dengan time series tahun
2010-2019. Balai Besar Karantina Pertanian (2012) menetapkan kode HS untuk bunga melati segar adalah 060390. Revealed Comparative Advantag (RCA) dan Export Product Dynamic (EPD) digunakan untuk mengetahui daya saing bunga melati putih. Granabetter (2016) menjelaskan Stellian \& DannaBuitrago (2019) menjelaskan bahwa RCA adalah konsep kunci dalam ekonomi internasional: jika keunggulan komparatif menentukan arus perdagangan, maka arus perdagangan dapat digunakan untuk menghitung indeks yang mengungkapkan keunggulan komparatif. Nilai RCA dihitung dengan rumus berikut: 


$$
R C A=\frac{X i j /{ }_{\Sigma j X i j}}{X w i /_{\Sigma X w}}
$$

\section{Keterangan :}

$\begin{aligned} \mathrm{i}= & \text { Komoditas } \mathrm{i} \\ \mathrm{j} & =\text { Negara } \mathrm{j} \\ \mathrm{RCA}= & \text { Revealed Comparative } \\ & \text { Advantage } \\ \boldsymbol{\Sigma} \mathrm{jXij}= & \text { Nilai ekspor komoditas } \\ & \text { i negara } \mathrm{j} \\ \mathrm{Xij}= & \text { Nilai ekspor seluruh } \\ & \text { komoditas di negara } \mathrm{j} \\ \mathrm{Xwi}= & \text { Nilai ekspor } \\ & \text { komoditas i di dunia }\end{aligned}$

$$
\begin{aligned}
\Sigma \mathrm{jXw}= & \text { Nilai ekspor seluruh } \\
& \begin{array}{l}
\text { komoditas di seluruh } \\
\text { dunia }
\end{array}
\end{aligned}
$$

(Laursen, 2015).

Selanjutnya, dilakukan penghitungan nilai EPD (Export Product Dynamic) dengan tujuan memetakan keberadaan daya saing bunga melati putih ke dalam 4 kuadran dengan masing-masing kategori yakni: lost opportunity, rising star, retreat dan falling star seperti yang digambarkan pada Gambar 2 berikut diadopsi dari Estherhuizen dalam (Hasibuan et al., 2012).

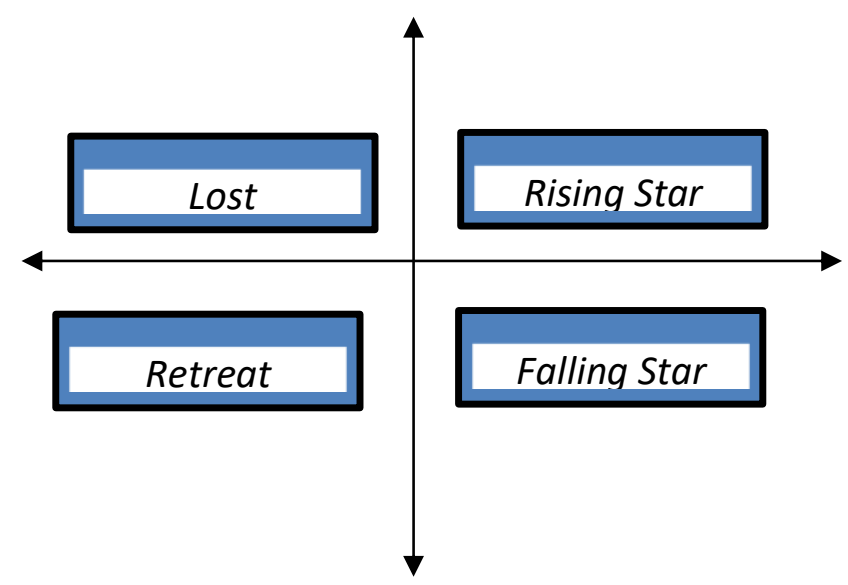

Gambar 2 : Posisi Keberadaan Komoditas Berdasarkan Perhitungan EPD

Penentuan posisi komoditas berdasarkan EPD dilakukan melalui perhitungan pada rumus berikut: Sumbu X (Pasar ekspor komoditas i) $\sum_{t=1}^{t}\left(\frac{X i j}{W i j}\right) t \times 100 \%-\sum_{t=1}^{t}\left(\frac{X i j}{W i j}\right)_{t-1} \mathrm{X}$ $100 \%$

Sumbu Y (Pangsa Pasar Produk)

$\sum_{t=1}^{t}\left(\frac{X t}{W t}\right) t \quad \mathrm{x} \quad 100 \%-\sum_{t=1}^{t}\left(\frac{X t}{W t}\right)_{t-1} \mathrm{X}$ $100 \%$

Dimana:
Xij = Nilai ekspor bunga melati putih Indonesia di negara tujuan ekspor

Wij = Nilai ekspor bunga melati putih dunia di negara tujuan ekspor

$\mathrm{Xt}=$ Total nilai ekspor semua komoditas Indonesia di negara tujuan ekspor

$\mathrm{Wt}=$ Total nilai ekspor seluruh komoditas dunia

$\mathrm{t}=$ Tahun ke $\mathrm{t}$

$\mathrm{t}-1=$ Tahun sebelum $\mathrm{t}$ 
Posisi pasar dalam EPD juga disajikan dalam matriks sesuai dengan
Estherhuizen dalam Yanti seperti berikut:

Tabel 2 : Matriks Posisi Pasar EPD (Export Product Dynamic)

\begin{tabular}{lll}
\hline Share of country's export in & \multicolumn{2}{c}{ Share of product in world trade } \\
\cline { 2 - 3 } world trade & Rising (dynamic) & Falling (stagnant) \\
\hline Rising (competitiveness) & Rising star & Falling star \\
Falling(non-competitiveness) & Lost opportunity & Retreat \\
\hline
\end{tabular}

Tahap terakhir adalah melakukan optimis; pengembangan pasar potensial; analisis X-model yaitu menggabungkan pengembangan pasar kurang potensial; dan informasi dari RCA dan EPD sehingga pengembangan pasar tidak potensial. diperoleh kemungkinan potensi Ketentuan pembagian potensi pasar pengembangan pasar. Empat berdasarkan X-model dirangkum pada kemungkinan potensi pasar dari $X-$ Tabel 3 berikut: model yaitu pengembangan pasar

Tabel 3: Ketentuan Potensi Pengembangan Pasar dalam X-Model

\begin{tabular}{|c|c|c|}
\hline EPD & RCA > 1 & RCA $<1$ \\
\hline Rising star & Pengembangan pasar optimis & Pengembangan pasar potensial \\
\hline Lost opportunity & Pengembangan pasa & $\begin{array}{l}\text { Pengembangan pasar kurang } \\
\text { potensial }\end{array}$ \\
\hline Falling star & Pengembangan pasar potensial & $\begin{array}{l}\text { Pengembangan } \\
\text { potensial }\end{array}$ \\
\hline Retreat & $\begin{array}{l}\text { Pengembangan pasar kurang } \\
\text { potensial }\end{array}$ & $\begin{array}{l}\text { Pengembangan } \\
\text { potensial }\end{array}$ \\
\hline
\end{tabular}

\section{HASIL DAN PEMBAHASAN} Perhitungan RCA Bunga Melati Putih Indonesia Tahun 2010-2019

Pada bagian ini disajikan informasi tentang nilai RCA bunga melati putih yang menjelaskan posisi daya saing komodita tersebut di dunia. Perubahan nilai RCA ditunjukkan gambar 3. Grafik pada Gambar 3 merupakan informasi yang diperoleh dari perhitungan nilai RCA. Gambar tersebut menunjukkan bahwa dalam kurun waktu 10 tahun yakni tahun 2010-2019 hanya terdapat satu kali nilai RCA > 1 yakni pada tahun 2012 yaitu 1,56 . 
Nilai RCA Bunga Melati Putih

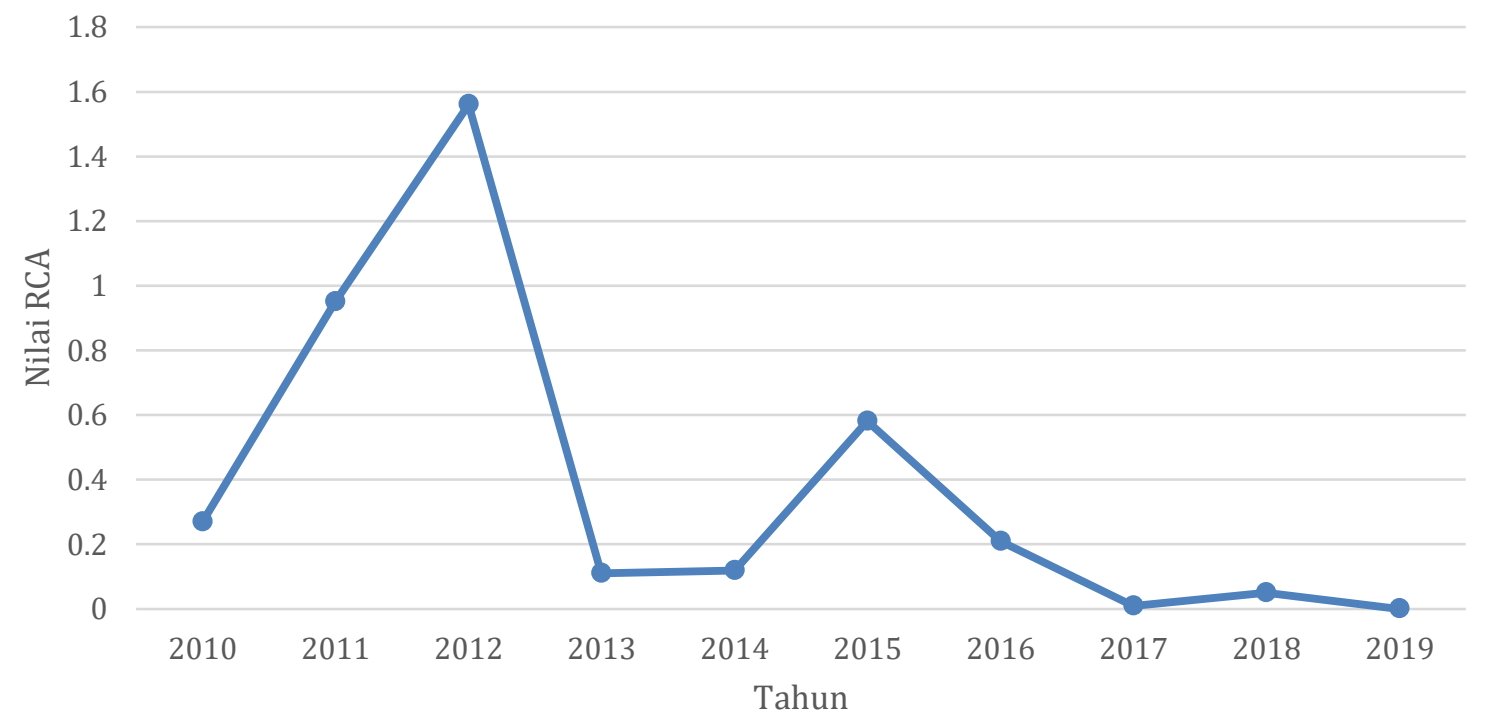

Sumber: Data Diolah, 2021

Gambar 3: Nilai RCA Bunga Melati Putih Indonesia (2010-2019)

Pada tahun tersebut diperoleh informasi bahwa nilai ekspor melati sebesar US\$ 8.969 merupakan nilai ekspor melati tertinggi sepanjang tahun 2010-2019. Hal tersebut disebabkan karena pada tahun tersebut negara Amerika Serikat, Inggris dan Belanda masih mengandalkan bunga melati putih dari Indonesia. Adapun volume ekspor bunga melati putih dalam kurun waktu 2010-2019 ditunjukkan pada tabel berikut

Tabel 4: Volume Ekspor Bunga Melati Putih Indonesia Tahun 2010-2019

\begin{tabular}{llrr}
\hline No & Tahun & Volume Ekspor $(\mathbf{K g})$ & Harga/Kg \\
\hline 1 & 2010 & 1.156 .896 & 1,50 \\
2 & 2011 & 1.536 .731 & 3,81 \\
3 & 2012 & 1.850 .149 & 4,85 \\
4 & 2013 & 422.928 & 1,80 \\
5 & 2014 & 562.886 & 1,24 \\
6 & 2015 & 2.813 .569 & 0,93 \\
7 & 2016 & 1.017 .270 & 1,21 \\
8 & 2017 & 101.788 & 0,30 \\
9 & 2018 & 279.571 & 0,94 \\
10 & 2019 & 1.776 & 1,35 \\
\hline
\end{tabular}

Tabel 4 menunjukkan bahwa harga tertinggi bunga melati putih per kg terjadi pada tahun 2012 yakni sebesar US $\$ 4,85$. Sementara, pada tahun 2015 dimana volume ekspor paling tinggi tidak mampu memberikan nilai RCA $>1$ karena pada tahun tersebut harga per kg bunga melati putih hanya mencapai US\$ $0,93 / \mathrm{kg}$. Hal tersebut senada dengan penelitian Pradipta (2015) yang tidak menyebutkan volume ekspor sebagai faktor yang 
mempengaruhi daya saing ekspor suatu komoditas. Volume ekspor yang tinggi akan menciptakan nilai RCA yang besar $(>1)$ apabila harga jual per unit komoditas tersebut juga tinggi. Sesuai dengan yang diutarakan oleh Muttoharoh et al., (2018); Kurniawati et al., (2019) bahwa salah satu faktor yang mempengaruhi ekspor suatu komoditas adalah harga internasional komoditas tersebut. Tingginya harga melati putih Indonesia pada tahun 2012 disebabkan oleh tingginya permintaan dari negara tujuan utama. Sementara pada tahun 2013 hingga 2019 permintaan dari Belanda, Inggris dan Amerika Serikat menurun karena pada rentang waktu tersebut permintaan dalam tiga negara tersebut dipenuhi dengan mengimpor bunga melati dari negara yang memiliki jarak lebih dekat dibandingkan dengan Indonesia seperti Jerman, Spanyol, Italia, Kolombia dan Ekuador.

\section{Nilai RCA Bunga Melati Putih Indonesia} Pada Setiap Negara Tujuan Ekspor

Dari pembahasan sebelumnya dapat dipastikan bahwa bunga melati putih Indonesia tidak berdaya saing secara global. Namun demikian, perlu dilakukan perhitungan daya saing komoditas tersebut pada tiap-tiap negara tujuan utama ekspor untuk mengetahui potensi pengembangan ekspor ke negara bersangkutan. Berdasarkan pertimbangan tersebut maka tabel berikut ini menyajikan informasi tentang nilai RCA bunga melati putih Indonesia di berbagai negara.
Tabel 5: Nilai Rerata RCA Bunga Melati Putih Indonesia Berdasarkan Negara Tujuan Ekspor Utama 2010-2019

\begin{tabular}{clcc}
\hline No & Negara & RCA & $\begin{array}{c}\text { Daya } \\
\text { Saing }\end{array}$ \\
\hline 1 & China & 5,9 & Kuat \\
2 & Jepang & 4,4 & Kuat \\
3 & Australia & 4,6 & Kuat \\
4 & Vietnam & 2,7 & Kuat \\
5 & Singapura & 16,1 & Kuat \\
6 & Malaysia & 0,2 & Lemah \\
7 & Belanda & 0,0 & Lemah \\
8 & Inggris & 0,8 & Lemah \\
& Amerika & & \\
9 & Serikat & 6,6 & Kuat \\
\hline Sumber: & UN-COMTRADE 2021 (diolah)
\end{tabular}

Tabel 5 menunjukkan bahwa daya saing bunga melati putih Indonesia terkuat ada di negara singapura, diikuti dengan Amerika Serikat, disusul negara China, Australia, Jepang, dan Vietnam. Sementara di negara Malaysia, Belanda dan Inggris, bunga melati putih Indonesia tidak berdaya saing. Menurut Palupi et al., (2019) ekspor bunga melati putih Indonesia ditujukan untuk memenuhi kebutuhan upacara keagamaan dan bahan baku industri. Seperti tingginya permintaan bunga melati putih dari negara Singapura. Prasetyo et al., (2020) mengatakan bahwa permintaan bunga melati putih di Singapura pada hari-hari biasa lebih tinggi dibandingkan dengan perayaan hari tertentu sesuai dengan penanggalan Islam di Indonesia.

Daya saing bunga melati putih di Amerika Serikat dalam kurun waktu tahun 2010-2019 adalah kuat karena dalam rentang tahun 2010-2015, 
Amerika Serikat selalu melakukan impor bunga melati putih dari Indonesia. Namun perlu diperhatikan bahwa mulai tahun 2016-2019 aktivitas ekspor melati putih ke negara ini berhenti. Hal tersebut disebabkan adanya pesaing eksportir baru seperti data yang ditunjukkan oleh UNCOMTRADE (2021) yaitu negara Ekuador dari wilayah Amerika Selatan yang jaraknya lebih dekat ke Amerika Serikat dibandingkan dengan negara Indonesia.

Bunga melati putih Indonesia tidak memiliki daya saing di negara tetangga yaitu Malaysia disebabkan karena negara ini merupakan produsen bunga melati putih meskipun pada keadaan tertentu mengimpor bunga melati putih dari Indonesia. Lemahnya daya saing bunga melati putih Indonesia di negara Belanda adalah karena negara ini merupakan produsen bunga melati putih dan dalam kondisi tertentu akan mengimpor melati putih dari Indonesia. Persaingan bunga melati putih Indonesia di negara Inggris mengalami kondisi yang sama terkait dengan pesaing eksportir di Negara Amerika Serikat yaitu masuknya supply melati putih dari negara Ekuador.

\section{Potensi Ekspor Bunga Melati Putih Indonesia}

Penting untuk mengetahui potensi ekspor komoditas di negara tujuan supaya mampu mnciptakan kebijakan yang sangat berperan dalam menjaga komoditas tersebut tetap berdaya saing seperti informasi di Tabel 6

Tabel 6: Posisi Ekspor Bunga melati Putih di Negara Tujuan

\begin{tabular}{llccc}
\hline No & Negara & $\begin{array}{c}\text { Pertumbuhan } \\
\text { Pangsa Pasar } \\
\text { Ekspor (\%) }\end{array}$ & $\begin{array}{c}\text { Pertumbuhan } \\
\text { Pangsa Pasar } \\
\text { Produk (\%) }\end{array}$ & Keterangan \\
\hline 1 & China & $-12,91$ & 0,014 & Lost Opportunity \\
2 & Jepang & $-0,16$ & 0,022 & Lost Opportunity \\
3 & Australia & 0,04 & 0,011 & Rising Star \\
4 & Vietnam & 0,10 & 0,020 & Rising Star \\
5 & Singapura & 0,02 & 0,036 & Rising Star \\
6 & Malaysia & $-0,018$ & 0,043 & Lost Opportunity \\
7 & Belanda & 0,01 & 0,006 & Rising Star \\
8 & Inggris & 0,006 & 0,002 & Rising Star \\
9 & Amerika Serikat & $-0,006$ & 0,007 & Lost Opportunity \\
\hline
\end{tabular}

Sumber: UN-COMTRADE 2021 (diolah)

Dari Tabel 6 diketahui bahwa posisi ekspor bunga melati putih Indonesia pada kategori Lost Opportunity di empat negara yakni China, Jepang, Malaysia dan Amerika Serikat.
Posisi ini terjadi karena pertumbuhan pangsa pasar ekspor semua komoditas ke negara tersebut rendah. Posisi ekspor bunga melati putih berada pada level rising star di lima negara lainnya yakni 
Australia, Vietnam, Singapura, pemetaan terhadap X-model yaitu Belanda dan Inggris. menggabungkan nilai RCA dan

Posisi rising star ini didorong oleh persentasi pangsa pasar ekspor seluruh komoditas Indonesia menuju kelima negara tersebut bernilai positif. Selanjutnya dilakukan informasi posisi pasar berdasarkan perhitungan EPD untuk mengetahui potensi pengebangan ekspor bunga melati putih di negara tujuan ekspor seperti pada tabel berikut:

Tabel 7: Analisis X-Model Bunga Melati Putih Indonesia Di Negara Tujuan Ekspor 20102019

\begin{tabular}{clccc}
\hline No & \multicolumn{1}{c}{ Negara } & RCA & EPD & Keterangan \\
\hline 1 & China & 5,9 & Lost Opportunity & Potensial \\
2 & Jepang & 4,4 & Lost Opportunity & Potensial \\
3 & Australia & 4,6 & Rising Star & Optimis \\
4 & Vietnam & 2,7 & Rising Star & Optimis \\
5 & Singapura & 16,1 & Rising Star & Optimis \\
6 & Malaysia & 0,2 & Lost Opportunity & Kurang potensial \\
7 & Belanda & 0,0 & Rising Star & Potensial \\
8 & Inggris & 0,8 & Rising Star & Potensial \\
9 & Amerika Serikat & 6,6 & Lost Opportunity & Potensial \\
\hline
\end{tabular}

Sumber: Data Diolah 2021

Tabel 7 ini menunjukkan bahwa ada potensi pasar yang sangat optimis di tiga negara yaitu Australia, Vietnam dan Singapura serta ada 5 (lima) negara yang potensial menjadi tujuan ekspor melati putih Indonesia. Perlu untuk diketahui bahwa meskipun bunga melati putih Indonesia tidak berdaya saing di negara Belanda dan Inggris akan tetapi berdasarkan uji x-model bahwa bunga melati putih memiliki potensi pasar di kedua negara tersebut. Hanya terdapat satu negara yang potensi ekspor nya kurang potensial yakni Malaysia oleh karena itu, sebaiknya komoditas melati putih Indonesia diprioritaskan untuk diekspor ke negara Australia, Vietnam, Singapura, China, Jepang, Belanda, Inggris dan Amerika Serikat.

\section{SIMPULAN}

Bunga melati putih indonesia tidak memiliki daya saing secara global, namun memiliki daya saing pada beberapa negara tujuan utama ekspor yaitu di negara China, Jepang, Australia, Vietnam, Singapura dan Amerika Serikat. Potensi pengembangan ekspor melati putih Indonesia adalah optimis di negara Australia, Vietnam dan Singapura; Potensial di negara China, Jepang, belanda, Inggris dan Amerika Serikat; kurang potensial di negara Malaysia. Berdasarkan hasil penelitian ini, Indonesia memiliki potensi untuk menjadi eksportir 
bunga melati putih tersebesar di Asia dan tidak potensial di Benua Eropa dan Amerika. Hal ini disebakan selain jauhnya jarak distribusi, terdapat beberapa negara yang menjadi kompetitor di kedua benua tersebut seperti Jerman, Italia, dan Spanyol di Benua Eropa dan Ekuador di Benua Amrika.

Supaya mampu memenuhi permintaan pasar ekspor, maka produksi dan kualitas bunga melati putih Indonesia harus ditingkatkan dengan cara membantu petani dalam penyediaan sarana produksi serta edukasi dan pendampingan budidaya bunga melati putih supaya sesuai dengan kualitas yang diharapkan pasar ekspor.

\section{DAFTAR PUSTAKA}

Badan Karantina Pertanian RI. (2019). Begini Cara Barantan Agar Melati Indonesia Masuk Ekspor. Tabloid Sinar Tani. https://tabloidsinartani.com/deta il/industriperdagangan/karantina/7975Begini-Cara-Barantan-AgarMelati-Indonesia-Masuk-Ekspor

Balai Besar Karantina Pertanian. (2012). PENGELUARAN BUNGA MELATI SEGAR. 66, 37-39. http://bbkpsoetta.com/images/K arantina/Katalog/KT/sedang/2.d. DK.007. Bunga Melati.pdf

BPS. (2019). Buletin Statistik Perdagangan Luar Negeri. https://www.kharn.kr/mobile/ar ticle.html?no=7664

Granabetter, D. (2016). Revealed comparative advantage index: an analysis of export trade in the Austrian district of Burgerland. Review of Innovation and
Competitiveness, 2(2), 97-114. https://doi.org/10.32728/ric.20 $16.22 / 3$

Hasibuan, A. M., Nurmalina, R., \& Wahyudi, A. (2012). Analisis Kinerja dan Daya Saing Perdagangan Biji Kakao dan Produk Kakao Olahan Indonesia di Pasar Internasional. Jurnal Tanaman Industri Dan Penyegar, 3(1), 57-70. https://doi.org/ 10.21082/jtidp.v3n1.2012.p5770

Horti Indonesia. (2020). Indonesia Berpotensi Besar Jadi Eksportir Florikultura.

https://hortiindonesia.com/berit a/indonesia-berpotensi-besarjadi-eksportir-florikultura-besar

Kemenko RI. (2019). Program pengembangan hortikultura untuk mendukung ekspor dan ekonomi daerah. FGD Pengembangan Hortikultura Untuk Peningkatan Ekspor Dan Ekonomi Daerah. https://ekon.go.id/source/publi kasi/2.-paparan-deputi-bidangkoordinasi-pangan-danpertanian-kemenko-ekon.pdf

Kurniawati, R. D. W. I., Studi, P., Pembangunan, E., Ekonomi, F., Bisnis, D. A. N., \& Surakarta, U. M. (2019). Analisis faktor-faktor yang mempengaruhi daya saing ekspor teh indonesia.

Laursen, K. (2015). Revealed comparative advantage and the alternatives as measures of international specialization. Eurasian Business Review, 5(1), 99-115. https://doi.org/ 10.1007/s40821-015-0017-1

Muttoharoh, V., Nurjanah, R., \& Mustika, C. (2018). Daya Saing dan Faktor-faktor yang Mempengaruhi Ekspor Kopi 
Arabika Indonesia di Pasar Internasional. E-Journal Perspektif Ekonomi Dan Pembangunan Daerah, 7(3)(3), 127-136. https://online-journal.unja.ac.id/ pdpd/article/view/6904/4330

Palupi, T. I., Prasetyo, E., \& Mukson, M. (2019). ANALISIS PENDAPATAN USAHATANI BUNGA MELATI (Jasminum sambac) DI KABUPATEN BATANG PROVINSI JAWA TENGAH. SOCA: Jurnal Sosial, Ekonomi Pertanian, 13(3), $396 . \quad$ https://doi.org/ 10.24843/soca.2019.v13.i03.p09

Pradipta, A. (2015). Posisi Daya Saing Dan Faktor-Faktor Yang Memengaruhi Ekspor BuahBuahan Indonesia. Jurnal Manajemen \& Agribisnis, 11(2), 129-143. https://doi.org/ 10.17358/jma.11.2.129-143

Prasetyo, E., Ekowati, T., Mukson, \& Gayatri, S. (2020). Financial Feasibility Analysis of Jasmine Flower (Jasminum Sambac L.)

Farming Business in Batang Regency, Central Java. IOP
Conference Series: Earth and Environmental Science, 518(1). https://doi.org/10.1088/17551315/518/1/012002

Purwaning Astuti, I., \& Juniwati Ayuningtyas, F. (2018). Pengaruh Ekspor Dan Impor Terhadap Pertumbuhan Ekonomi Di Indonesia. Jurnal Ekonomi \& Studi Pembangunan, 19(1). https://doi.org/10.18196/jesp.1 9.1.3836

Stellian, R., \& Danna-Buitrago, J. (2019). Revealed comparative advantages and regional specialization: Evidence from Colombia in the Pacific Alliance. Journal of Applied Economics, 22(1), 349-379. https://doi.org/10.1080/151403 26.2019.1627722

Yanti, L. (2012). Daya Saing Produk Turunan Susu Indonesia Di Pasar Dunia. Jurnal Manajemen \& Agribisnis, 9(3), 183-193. https://doi.org/10.17358/jma.9. 3.183-193 